\author{
Науковий вісник Дьвівського національного університету \\ ветеринарної медицини та біотехнологій імені С.3. Гжицького
}

\author{
Scientific Messenger of Lviv National University \\ of Veterinary Medicine and Biotechnologies
}

UDC 637.5

\title{
The influence of a microbiological derived protease on the autolysis process in meat of broiler chickens
}

\author{
D. Shvedyuk ${ }^{1}$, V. Pasichnyi ${ }^{1}$, O. Moroz ${ }^{2}$, A. Heredchuk $^{3}$ \\ ${ }^{I}$ National University of Food Technologies, Kyiv, Ukraine \\ ${ }^{2}$ Lviv State College of Food and Processing Industry of National University of Food Technologies, Lviv, Ukraine \\ ${ }^{3}$ Poltava University of Economics and Trade, Poltava, Ukraine
}

Article info

Received 07.09.2018

Received in revised form 05.10 .2018

Accepted 08.10.2018

National University

of Food Technologies,

Volodymyrska Str., 68, Kyiv, 01033, Ukraine.

Tel.: + 38-068-469-93-44

E-mail: shvedyuk.d@ukr.net, pasww1@ukr.net

Lviv State College of Food and Processing Industry of National University of Food Technologies,

l Pul uya Str., 42, Lviv,

79060, Ukraine.

Poltava University of Economics and Trade, Koval Str., 3, Poltava, 36014, Ukraine.

\begin{abstract}
Shvedyuk, D., Pasichnyi, V., Moroz, O., \& Heredchuk, A. (2018). The influence of a microbiological derived protease on the autolysis process in meat of broiler chickens. Scientific Messenger of Lviv National University of Veterinary Medicine and Biotechnologies. 20(90), 32-35. doi: $10.32718 /$ nvlvet 9007
\end{abstract}

The article is devoted to the influence of protease of microbiological origin on the autolysis process in broiler chicken meat. Protease made by Aspergillus fungi was chosen as an enzym. According to the experiment plan, 5 samples were made, including a control sample, in which autolytic processes were performed without the addition of an enzyme. The experimental group (samples I-IV) included samples with 30, 50, 70 and $90 \mathrm{mg}$ of the added enzyme solution, respectively, per $100 \mathrm{~g}$ of basic meat raw material. After introduction of the enzyme and parallel fixation of the studied control parameters before maturation, the samples were stored at $4-6{ }^{\circ} \mathrm{C}$ for 2 days. The selected physicochemical parameters were studied in all samples after 1 and 2 days of storage. Among the parameters studied, the following were selected: $p H$, water-holding capacity (WHC), water binding capacity (WBC), fat binding capacity (FBC), moisture content, and optical density by measuring of soluble and water-soluble proteins volume. Examenated transition of proteins from salt- to water-soluble experimental group also as their overall solubility is noticeably higher than in the control sample. Among the functional and technological characteristics, these samples have shown a high pH and WHC levels. The WBC, FBC and total water content show a slight increase. The values of the studied parameters among the samples I-IV have not shown a noticeable difference. For research minced meat at 48 hours of maturation compared with the control, the increase of WHC was accordingly from 16.4 to $18.4 \%$, the value of the university increased by $9.1-19.1 \%$, and FBC by 1.1-5.9\%. At the same time, the change in the proportion of salt and algae protein substances of minced meat according to the optical density for 48 hours of maturation was equalized with the control and the variation of this index fluctuated within 1-2 units. A literature and studies sources review have shown the effectiveness of microbial-derived protease enhancement under the action of protease ASP on the functional-technological indices of white meat of broiler chickens. It has been determined that when injecting into broth from chicken broiler meat, ASP proteases in an amount of 30 to $90 \mathrm{mg}$ per $100 \mathrm{~g}$ of raw materials, an increase in the thermal stability indices for FBC by 1.1-5.9\%, in higher education institutions by 9.1-19.1\%, which makes it possible to effectively model the increase in the functional and technological characteristics of minced meat from the amount of enzyme addition and maturation time.

Key words: proteases, fermentation, poultry meat, functional and technological properties, physicochemical properties, autolysis.

\section{Вплив протеази мікробіологічного походження на процес автолізу у м'ясі курчат-бройлерів}

\author{
Д.А. Шведюк ${ }^{1}$, В.М. Пасічний ${ }^{1}$, О.О. Мороз $^{2}$, А.М. Гередчук ${ }^{3}$ \\ ${ }^{1}$ Національний університет харчових технологій, м. Київ, Украӥна \\ ${ }^{2}$ Львівський державний коледж харчової і переробної промисловості Національного університету харчових \\ технологій, м. Львів, Украӥна
}




\section{${ }^{3}$ Полтавський університет економіки і торгівлі, м. Полтава, Украӥна}

Стаття присвячена впливу протеази мікробіологічного походження на прочес автолізу в м'ясі курчат-бройлерів. Як фермент обрана протеаза, що продукується грибами виду Aspergillus. Згідно з планом експерименту розроблено 5 зразків, включаючи контрольний, у якому автолітичні прочеси проходили без внесення ферменту. Дослідна група (зразки I-IV) включала в себе зразки, у які вносили відповідно 30, 50, 70 та 90 мг розчину ферменту на 100 г основної м'ясної сировини. Після внесення ферменту та паралельної фіксаиї̈ досліджуваних показників контролю перед дозріванням, зразки зберігали за температури 4-6 ${ }^{\circ} \mathrm{C}$ протягом 2 діб. Обрані фізико-хімічні показники досліджували в усіх зразках після 1 та 2 діб зберігання. Серед досліджуваних показників обрано наступні: pН, вологозв'язувальна здатність (В3З), вологоутримувальна здатність (ВУЗ), жироутримуюча здатність (ЖУЗ), вологовміст, оптична густина при вимірюванні солерозчинних та водорозчинних білків. В дослідній групі виражений перехід білків із соле- до водорозчинних, а їхня загальна розчинність помітно вища, ніж у контрольному зразку. Серед функиіональнотехнологічних характеристик дані зразки показують вищий рівень рН та ВЗЗ. Показники ВУЗ, ЖУЗ та загальний вологовміст демонструють незначне зростання. У значеннях досліджуваних показників серед зразків I-IV нема помітної різниці. Загалом, проведені дослідження демонструють позитивний вплив протеази мікробіологічного походження на фізико-хімічні характеристики м'яса курчат-бройлерів.

Ключові слова: протеази, ферментація, м'ясо птиці, функціонально-технологічні показники, фізико-хімічні показники, автоліз.

\section{Вступ}

Враховуючи те, що протеази мікробіологічного походження мають нижчу за синтетичні аналоги собівартість, а також здатні вирішувати цілу низку завдань залежно від підвидів мікроорганізмів, які $\epsilon$ їхніми продуцентами, перспективним є дослідження впливу цих ферментів на основні види м'ясної сировини (Currin et al., 2015).

Цвілеві гриби роду Aspergillus одомашнені понад 1500 років тому на території Азії. Використання цього виду організмів може мати різне призначення - залежно від підвидів грибів. Першим 3 досліджених призначень аспергил $€$ їх здатність до гідролізу білків рослинної сировини. Таким чином, історично ці організми беруть участь у ферментативних процесах в технології виготовлення соєвого соусу (Souza et al., 2015). Також підвид даних грибів, відомий як “пліснява Кодзі”, широко застосовують для розщеплення крохмалю на моносахариди для пришвидшення процесів молочнокислого бродіння у технології традиційних алкогольних напоїв країн Сходу (найбільш відомий приклад - саке) (Bekhit et al., 2014). Також відомою є дія ферментів, що продукуються Aspergillus oryzae на білки м'ясної сировини (Al Loman and Ju, 2016).

Колективом вчених 3 Нової Зеландії проведено порівняльний аналіз протеаз різного походження (не включаючи тваринні) 3 точки зору їх впливу на консистенцію м'ясної сировини (Bekhit et al., 2014). Використання екзогенних протеаз для поліпшення консистенції м'яса останнім часом викликає великий інтерес. Дані ферменти можуть бути використані для виробництва ніжного м'яса та поліпшення органолептичних характеристик низькосортної сировини (Shvediuk and Pasichnyi, 2018). Серед усіх екзогенних протеаз для розм'якшення м'ясної сировини найтиповішими є такі, як папаїн, бромелайн і фицин. Нові рослинні протеази (актінідін і зінгібаін) і мікробні ферментні препарати останнім часом визнані перспективними завдяки більш контрольованому впливу на м'ясну сировину і перевагу в ціні. Успішне використання цих ферментів у свіжому м'ясі вимагає визначення їх ферментативної кінетики і характеристик, а також розуміння впливу умов навколишнього середо- вища на м'ясну сировину ( $\mathrm{pH}$, температура) та ферментативну активність, зміну розчинності фракцій білків, які впливають на функціонально-технологічні показники м'ясної сировини (Pasichnyi et al., 2008). Це дозволяє створювати оптимальні умови для виробництва свіжого м'яса і усувати або зменшувати будь-які негативні впливи на інші якісні характеристики (Ukrainets et al., 2017).

Таким чином, оптимальними 3 точки зору технології та собівартості визнано такі ферменти, які мають найбільш контрольовану активність та є найстабільнішими. Ферменти, які продукуються грибами Aspergillus, цілком відповідають цим вимогам. Також важливим $\epsilon$ те, що ці ферменти можуть одночасно ферментувати і білки рослинної сировини. Це дає можливість розробки комбінованих м'ясо-рослинних продуктів підвищеної біологічної цінності (Shvediuk et al., 2016).

Метою проведених досліджень було дослідити вплив ферментації за допомогою протеаз мікробіологічного на хід процесу автолізу у м'ясі курчат бройлерів.

Об'єктом досліджень $є$ м'ясо курчат-бройлерів та протеаза мікробіологічного походження, що продуктується грибами виду Aspergillus spp (надалі в тексті ASP [Aspergillus spp protease]).

Згідно 3 планом експерименту досліджували 5 зразків фаршу білого м'яса курчат бройлерів (подрібнення 2-3 мм), що відрізнялись рівнем введення ферменту. Кількість внесеної протеази ASP для зразків I-IV відповідно становила 30, 50, 70 та 90 мг ферменту на кожні 100 г м'ясного фаршу. Контролем слугував зразок, автоліз у якому проходив без внесення протеази ASP. Дозрівання усіх зразків проходило протягом 1 і 2 діб за температури 4-6 ${ }^{\circ} \mathrm{C}$. На початку ферментації та після 1 та 2 діб дозрівання було досліджено фізикохімічні показники фаршів. У процесі досліджень визначали: значення $\mathrm{pH}$, вологозв'язуючу здатність (ВЗЗа), вологоутримувальну здатність (ВУЗ), жироутримувальну здатність (ЖУЗ), вміст вологи, значення оптичної густини екстрактів при визначенні вмісту солерозчинних та водорозчинних білків у дослідних зразках фаршів. 


\section{Матеріал і методи досліджень}

Вимірювання $\mathrm{pH}$ проводили потенціометричним методом, вологовміст - арбітражним методом, а ВЗ3а - методом пресування (Strashynskyi et al., 2016). Вимірювання оптичної густини проводилось за біуретовим методом (Hou et al., 2014). Вимірювання ЖУЗ та ВУЗ проводилось за допомогою жироміра за арбітражним методом (Paska et al., 2014).

Вибір даних фізико-хімічних та функціональнотехнологічних характеристик обумовлений сукупністю факторів. Визначення $\mathrm{pH}$ та вологості фаршів дає можливість сформувати уявлення про базові зміни їх функціонально-технологічних характеристик. Значення ВЗЗа відображає технологічний потенціал обраної сировини та функціональність їі білків. Визначення ВУЗ та ЖУЗ проводилось 3 метою виявлення впливу направленої ферментації на термостабільність фаршів і можливість підвищення функціональнотехнологічних характеристик м'яса курчат-бройлерів. Показники оптичної густини екстрактів 3 м'ясного фаршу, визначені за біуретовим методом, дозволили визначити відносну зміну кількості водо- та солерозчинних білків фаршевої системи, не застосовуючи при цьому калібрувальних графіків.

Відмова від калібрувальних графіків обумовлена тим, що їх побудова під кожен коректний вид продукту вимагає великих обсягів роботи і ускладнена через специфічні оптичні характеристики розчину ферменту (Unrean et al., 2013). 3 іншої точки зору, в процесі дослідження нас цікавить саме зміна властивостей та кількості різних груп білків у ході процесу, а не їхня абсолютна кількість, яка залежить від багатьох факторів, що характеризують якість м'ясної сировини (Klymenko et al., 2006).

\section{Результати та їх обговорення}

В табл. 1 представлено значення досліджуваних показників за дослідними варіантами на 1 і 2 добу дозрівання фаршів з внесенням протеази ASP.

3 наведених у табл. 1 даних видно, що фонове значення показників фаршу 3 білого м'яса курчатбройлерів за своїми характеристиками не відрізнялось від традиційних показників даної сировини (Klymenko et al., 2006). В процесі дозрівання контрольний зразок фаршу без внесення протеази демонстрував типову зміну значень основних показників. На першу 24 годину дозрівання відбувалось збільшення значень В3За на 34,2\%, незначне підвищення значення ВУЗ на 2,7\%, при зниженні ЖУЗ більше ніж на 6\%, тимчасом як на 48 годину дозрівання показник ВЗЗа контрольного фаршу порівняно з 24 годинами дозрівання знизився на $13,4 \%$, ВУЗ збільшився на 5,9\% порівняно з фоном і відбулось практичне відновлення значень ЖУЗ до фонового.

\section{Таблиця 1}

Характеристики фаршів м'яса курчат-бройлерів в часі дозрівання з внесеною протеазою ASP

\begin{tabular}{|c|c|c|c|c|c|c|c|}
\hline \multirow[t]{2}{*}{ Назва } & \multirow[t]{2}{*}{$\mathrm{pH}$} & \multirow[t]{2}{*}{ В3За, $\%$} & \multirow{2}{*}{$\begin{array}{c}\text { ВУ3, } \\
\%\end{array}$} & \multirow{2}{*}{$\begin{array}{l}\text { ЖУЗ, } \\
\%\end{array}$} & \multirow{2}{*}{$\begin{array}{c}\text { Вміст } \\
\text { вологи, \% }\end{array}$} & \multicolumn{2}{|c|}{$\begin{array}{c}\text { Показник оптичної густини водних } \\
\text { розчинів білків, од. }\end{array}$} \\
\hline & & & & & & Солерозчинні & Водорозчинні \\
\hline \multicolumn{8}{|c|}{ Без дозрівання (фон) } \\
\hline Контроль & 6,05 & 54,82 & 47,4 & 72,0 & 73,15 & 92 & 91,5 \\
\hline \multicolumn{8}{|c|}{ На першу 24 годину дозрівання } \\
\hline Контроль & 6,20 & 73,60 & 48,70 & 67,50 & 74,34 & 91 & 92 \\
\hline Зразок I & 6,40 & 74,75 & 54,30 & 66,80 & 75,60 & 89 & 95 \\
\hline Зразок II & 6,50 & 73,50 & 53,90 & 69,20 & 73,82 & 94 & 96 \\
\hline Зразок III & 6,50 & 70,10 & 55,50 & 65,50 & 74,32 & 92 & 94 \\
\hline Зразок IV & 6,55 & 69,85 & 57,10 & 68,40 & 75,42 & 91 & 93 \\
\hline \multicolumn{8}{|c|}{ На другу 48 годину дозрівання } \\
\hline Контроль & 6,70 & 63,74 & 50,20 & 70,20 & 77,32 & 87 & 86 \\
\hline Зразок I & 6,55 & 74,92 & 54,80 & 74,10 & 77.82 & 89 & 85 \\
\hline Зразок II & 6,60 & 75,50 & 56,40 & 73,30 & 78,54 & 87 & 88 \\
\hline Зразок III & 6,60 & 73,80 & 57,30 & 71,00 & 78,05 & 89 & 86 \\
\hline Зразок IV & 6,80 & 74,20 & 59,80 & 74,40 & 76,25 & 88 & 89 \\
\hline
\end{tabular}

Показники накопичення у фарші соле- та водорозчинних білкових речовин контролю були на 48 годину дозрівання, порівняно 3 фоном, вищими на 5-5,5 одиниць оптичної густини, що свідчить про накопичення розчинних білкових речовин за рахунок природних автолітичних змін у м'ясі курчат-бройлерів, що корелюється зі змінами рН на етапах дозрівання як для контролю, так і зразків з внесенням протеази ASP.

Для зразків фаршів з внесенням протеази ASP порівняно 3 фоном на 24 годину зберігання значення В3За при внесенні 30 мг ферменту були кращими, ніж у контрольного. При більшій частці ферменту на першу добу дозрівання ВЗЗа дещо поступається контро- лю. Однак за ефективністю підвищення значень ВУЗ, тобто підвищенням термостабільності фаршів внесення протеази проявляє достовірну тенденцію до збільшення на 12,1-17,2\%. По ЖУЗ таке підвищення склало на 24 годину дозрівання 2,0-2,5\%.

Для дослідних фаршів на 48 годину дозрівання, порівняно 3 контролем, збільшення ВЗЗа склало відповідно від 16,4 до 18,4\%, значення ВУЗ збільшилось на 9,1-19,1\%, а ЖУЗ на 1,1-5,9\%. Водночас зміна частки соле- і водорозчиннних білкових речовин фаршів за показником оптичної густини на 48 годину дозрівання вирівнювалась 3 контролем і варіювання даного показника коливалось в межах 1-2 одиниць. 


\section{Висновки}

Огляд літературних джерел та проведені дослідження доводять ефективність підвищення під дією протеази ASP мікробіологічного походження на функціонально-технологічних показників білого м'яса курчат-бройлерів. Визначено, що при внесенні на фарш 3 м'яса курчат-бройлерів протеази ASP в кількості від 30 до 90 мг на 100 г сировини досягається підвищення показників термостабільності щодо ЖУЗ на 1,1-5,9\%, ВУЗ - на 9,1-19,1\%, що дозволяє ефективно моделювати підвищення функціональнотехнологічних показників фаршів залежно від кількості внесення ферменту і часу дозрівання.

Перспективи подальших досліджень. Подальші дослідження будуть спрямовані на визначення раціональної кількості кухонної солі, цукрів та регуляторів кислотності для оптимізації спільного використання даних харчових добавок 3 протеазою ASP у складі м'ясних фаршів на основі традиційних видів м'ясної сировини і при їх комбінуванні 3 білкововмісними рослинними наповнювачами.

\section{References}

Currin, A., Swainston, N., Day, P.J., \& Kell, D.B. (2015). Synthetic biology for the directed evolution of protein biocatalysts: navigating sequence space intelligently. Chemical Society Reviews, 44(5), 1172-1239. doi: 10.1039/c4cs00351a.

Souza, P. M., Bittencourt, M.L.D.A., Caprara, C.C., Freitas, M.D., Almeida, R.P.C., Silveira, D., \& Magalhães, P.O. (2015). A biotechnology perspective of fungal proteases. Brazilian Journal of Microbiology, 46(2), 337-346. doi: 10.1590/S1517838246220140359 .

Bekhit, A.A., Hopkins, D.L., Geesink, G., Bekhit, A.A., \& Franks, P. (2014). Exogenous proteases for meat tenderization. Critical reviews in food science and nutrition, 54(8), 1012-1031. doi: 10.1080/10408398.2011.623247.

Al Loman, A., \& Ju, L.K. (2016). Towards complete hydrolysis of soy flour carbohydrates by enzyme mixtures for protein enrichment: a modeling approach. Enzyme and microbial technology, 86, 25-33. doi: 10.1016/j.enzmictec.2016.01.010.

Bekhit, A.A., Hopkins, D.L., Geesink, G., Bekhit, A.A., \& Franks, P. (2014). Exogenous Proteases for Meat Tenderization. Critical Reviews in Food Science and Nutrition, 54(8), 1012-1031, doi: 10.1080/10408398.2011.623247.

Shvediuk, D.A., \& Pasichnyi, V.M. (2018). Vykorystannia tsilovoi fermentatsii u tekhnolohii miasomistkykh produktiv podovzhenoho terminu zberihannia. Visnyk Natsionalnoho tekhnichnoho universytetu "KhPI". Se- riia: Novi rishennia $\mathrm{v}$ suchasnykh tekhnolohiiakh, 16(1292), 184-190 (in Ukranian).

Pasichnyi, V.M., Moroz, O.O., \& Zakhandrevych, O.A. (2008). Doslidzhennia kharakterystyk miasnykh farshiv $\mathrm{z}$ vykorystanniam $\mathrm{v}$ protsesi posolu molochnoi syrovatky ta sukhoho moloka. Naukovyi visnyk LNUVMT im. S.Z. Gzhytskoho, 10, 2(37), 101-104 (in Ukranian).

Ukrainets, A.I. Pasichnyi, V.M., Moroz, O.O., \& Nevodiuk, I.V. (2017). Vykorystannia bilkovykh napovniuvachiv u vyrobnytstvi napivkopchenykh kovbas. Naukovi pratsi Natsionalnoho universytetu kharchovykh tekhnolohii, 23(2), 226-233. http://nbuv.gov.ua/UJRN/Npnukht_2017_23_2_29 (in Ukranian).

Shvediuk, D.A., Pasichnyi, V.M., \& Prokhorenko, Zh.I. (2016). Doslidzhennia fizyko-khimichnykh vlastyvostei napivfabrykativ miasnykh $\mathrm{z}$ dodavanniam bilkovo-zhyrovykh emulsii na osnovi kupazhovanykh zhyriv. Visnyk Nats. tekhn. un-tu "KhPI": zb. nauk. pr. Ser.: Novi rishennia v suchasnykh tekhnolohiiakh, 42(1214), 223-227 (in Ukranian).

Strashynskyi, I.M., Pasichnyi, V.M., \& Fursik, O.P. (2016). Stabilizatsiia pokaznykiv farshiv varenykh kovbas z vykorystanniam bilokvmisnoi kompozytsii. Naukovi pratsi Natsionalnoho universytetu kharchovykh tekhnolohii, 22(1), 210-218. http://nbuv.gov.ua/UJRN/Npnukht_2016_22_1_26 (in Ukranian).

Hou, X., Liang, R., Mao, Y., Zhang, Y., Niu, L., Wang, R., \& Luo, X. (2014). Effect of suspension method and aging time on meat quality of Chinese fattened cattle M. Longissimus dorsi. Meat science, 96(1), 640-645. doi: 10.1016/j.meatsci.2013.08.026.

Paska, M.Z., Markovych, I.I., \& Symonov, R. (2014). Funktsionalno-tekhnolohichni pokaznyky napivkopchenykh kovbas iz chastkovoiu zaminoiu miasnoi syrovyny boroshnom sochevytsi. Naukovyi visnyk Lvivskoho natsionalnoho universytetu veterynarnoi medytsyny ta biotekhnolohii im. Gzhytskoho, 16, 3(4), 119-128. http://nbuv.gov.ua/UJRN/nvlnu_2014 $16 \quad 3 \% 284 \% 29 \_20$ (in Ukranian).

Unrean, P., Pimsamarn, J., Kitsubun, P., \& Tongta, A. (2013). Fuzzy logic control of rotating drum bioreactor for improved production of amylase and protease enzymes by aspergillus oryzae in solid-state fermentation. Journal of microbiology and biotechnology, 23(3), 335342. https://www.ncbi.nlm.nih.gov/pubmed/23462006.

Klymenko, M.M., Vinnikova, L.H., Bereza, I.H., \& Honcharov, H.I. (2006). Tekhnolohiia miasa ta miasnykh produktiv. Pidruch. K.: Vyshcha osvita (in Ukranian). 